\title{
Lip and Oral Cavity Cancer Pathologic Regional Lymph Nodes TNM Finding v6
}

National Cancer Institute

\section{Source}

National Cancer Institute. Lip and Oral Cavity Cancer Pathologic Regional Lymph Nodes

TNM Finding v6. NCI Thesaurus. Code C64418.

A pathologic finding about one or more characteristics of lip and oral cavity cancer,

following the rules of the TNM AJCC v6 classification system as they pertain to staging of regional lymph nodes. 